\title{
The 18th century Lublin in the eyes of a military engineer. Fortifications and security measures for the negotiations on the map of Lublin created by $C$. d'Örken and modern evidence confirming their existence
}

\begin{abstract}
Just as contemporary cartographic works, old maps were usually made for specific purposes, e.g. related to taxation, propaganda or military objectives. C. d'Örken's map of Lublin of 1716 is an example of a cartographic work created for military purposes, as it was made in the context of negotiations of the Tarnogród Confederation. The author of the map focused on the thematic content - he marked control zones, as well as military outposts, and accommodation sites. In many instances, the base content is presented with little attention to detail. There are a few exceptions to this rule, with fortifications being the most noticeable one. It was most likely motivated by the author's profession, as he was a military engineer. Still, although Lublin has never been a particularly well-fortified city, the aforementioned content of the map perfectly reflects not only the former shape of the city space, but also its contemporary organisation. This article, due to its detailed description of selected works and the methodology involving the use of old cartographic materials, can be used as an important source material for archaeological, restoration and regeneration works.
\end{abstract}

Keywords: Tarnogród Confederation, Lublin, old maps, city map, fortifications

\section{Introduction}

In the current era of ubiquitous information, the amount of data provided by city maps can be often overwhelming. Creation of a clear and effective map requires a lot of skill and a good sense of graphic balance. Old maps are often perceived as general works whose narrower scope of content results either from technical limitations or simply the fact that the number of objects to include on the map used to be lower. However, a closer look at old city maps reveals that such reasoning is not always correct, as old city maps include also detailed thematic maps containing surprisingly large amounts of information.

Many of such maps were created in response to specific orders or for specific purposes. Quite often, they would later became subjects of historical research, providing knowledge concerning not only topography of the city and the basic layout of streets and buildings, but also details not shown in many of contemporary city maps. Even if we limit our scope of interest only to the city of Lublin, it is worth mentioning such interesting city maps as the map of $\mathrm{K}$. Bekiewicz created in 1649 as a document related to the process of demarcation of monastery land (H. Gawarecki, B. Lenart 1954), and the police map created by L. Tosio in 1892 (P. Dymmel 2007). The map of Lublin created by C. d'Örken is a similar thematic work, and the circumstances of its preparation, as well as the scope of its thematic and base content, make it an important document concerning the city's history, with additional supra-regional significance.

The aim of this paper is to argue that the importance of old maps goes beyond their role in the process of learning about the history of a given geographical area and that they can also play significant roles in contemporary decisions concerning spatial planning. The 
author draws attention to the fact that maps need to be approached as works related to specific time periods, which can serve as historic source materials only if they are first correctly dated and identified, which often requires conducting prior interdisciplinary research. The author focuses on only one element of the map content - fortifications - and demonstrates the importance of historical and archaeological sources in the correct assessment of quality and credibility of their depiction.

\section{Map of Lubin - a "hotel brochure" for a specific occasion}

The 1716 city map of Lublin stands out among thematic maps of the city (fig. 1). It was prepared as an aid for the negotiations related to the Tarnogród Confederation, formed by Polish nobility against the Saxons and King Augustus II the Strong. The negotiations began in June of 1716 and four control zones, as well as related security measures, were established in the city at the end of July. This is the very situation which is shown in the hand-drawn map dated 6 August 1716 (K. Nieścioruk 2006). We do not know much about its author. It was probably a military engineer d'Örken whose surname was spelt incorrectly in many publications (e.g. J. Dybała 1972, E. Mitrus 1995, D. Kociuba 2003). It can be concluded that he probably arrived for the negotiations with the royal party and was given the task of drawing up the map. The scope of the map's content and its legend indicate that the map's main purpose was to provide participants of the negotiations with information on the organisational matters concerning this event. This is why the author chose not to focus on the precise, topographic description of the city area. The map contains many simplifications, the shapes of some buildings are deformed, and areas which were irrelevant from the point of view of

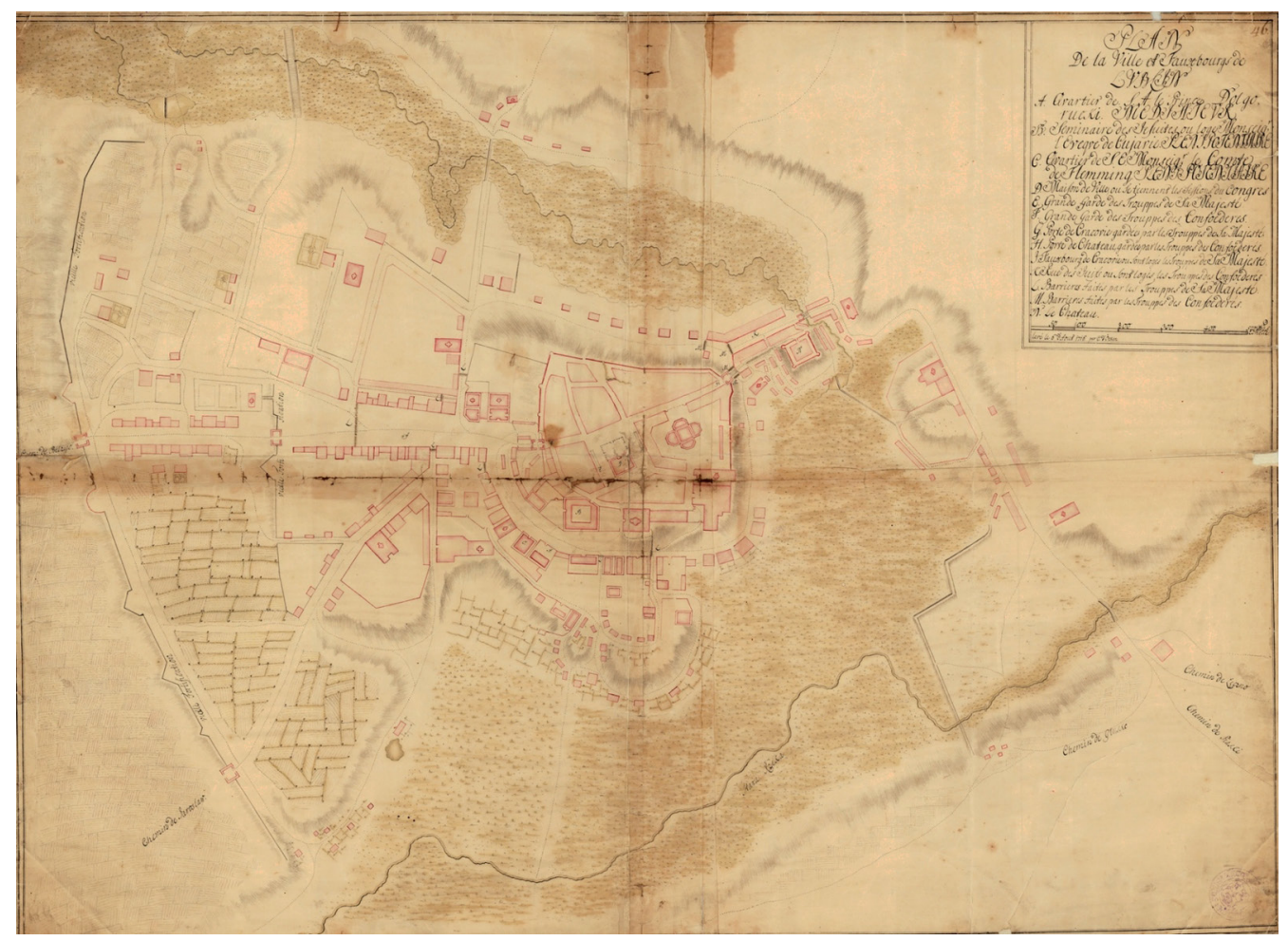

Fig. 1. City map of Lublin of 1716 (reduced size). Taken from: Leksykon. TeatrNN / Brama Grodzka (http://teatrnn.pl/leksykon/artykuly/c-d-orken-plan-de-la-ville-et-fauxbourgs-de-lublin-z-1716-roku) 
the needs of those who had commissioned the map were geometrically distorted (K. Nieścioruk 2006, pp. 116-117). On the other hand, the map presents in great detail information related to the quartering of the negotiations' participants, camps and outposts of the parties, as well as the areas of the city they controlled. Additionally, C. d'Örken placed a great emphasis on elements of the city's fortifications despite the fact that Lublin has never been an extraordinarily well-fortified city.

\section{The thematic content of the map}

The legend is a list which includes explanations of the letters used on the map. The first three indicate the accommodation sites of the most important people taking part in the negotiations. The letters $A$ and $C$ indicate palaces located at contemporary Królewska Street. The first of the palaces was occupied by Prince Dolgorukov, a mediator who represented the Russian Tsar during the negotiations, and the second by Count Flemming. The third person named in the legend was Bishop Szaniawski who lived in the now no-longer-existing Jesuit College (letter B on the map), located opposite the palaces occupied by the above-mentioned persons.

The negotiations took place at the Crown Tribunal in Lublin (D on the map), and the main camps of the royal $(E)$ and confederate $(F)$ parties were located nearby. The area of the today's Old Town - an area hidden within the city walls, with two main entrances - was guarded by both sides of the conflict who manned the above-mentioned entrances (fig. 2). The royal side guarded the Krakowska Gate $(G)$ and the confederate forces protected the Grodzka Gate $(\mathrm{H})$ which is described as the Castle Gate in the map's legend, as it leads to the Lublin Castle. Krakowskie Przedmieście Street was located just behind the Kraków Gate, and six royal military outposts were located in its vicinity. The forces guarded the area of Krakowskie Przedmieście up to (using today names) Staszica Street, the so-called Świętoduska Hillcock, as well as Królewska Street and Żmigród Street. The confederate forces also controlled a zone of the city. Their four outposts marked the borders of a much smaller area around the Grodzka Gate (fig. 3). Determining the exact range of this zone is difficult because of the changed

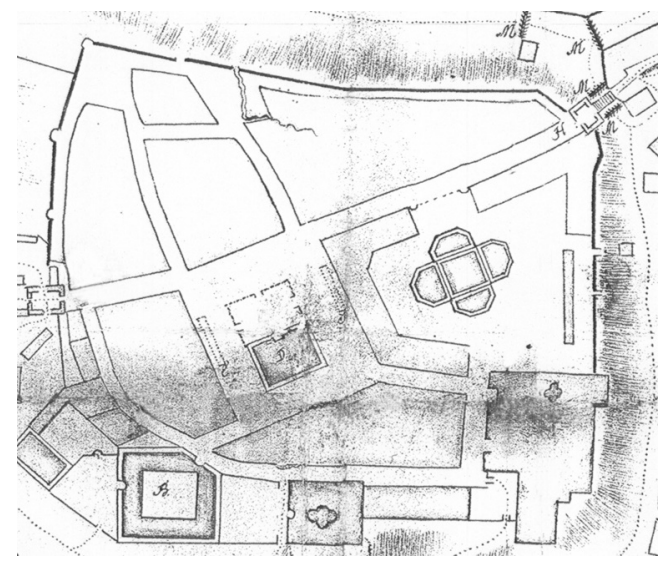

Fig. 2. A part of the map presenting the current organisation of the Old Town area

organisation of the city area and a rather symbolic depiction of the zone on the map. This is where the Jewish quarter was located until World War II, and today the area is organised in a completely different way, so it is difficult to assess the relation between the content of the old map and the contemporary area of the city.

The fact that the representatives of the Confederation were omitted from the legend and the fact that the zone they controlled was depicted in a less detailed manner may indicate that the map was commissioned by the royal party (or possibly by the tsar's mediator). This would suggest that the author, about whom we know very little except his surname, had some sort of relationship with the Saxons.

\section{The base content - fortifications}

The base content of the map can also provide some information about its author. For instance, the city's fortifications are depicted with great attention to detail. From the point of view of the negotiations, this element could have been seen as significant, but it would most likely concern mostly the city walls, not the fourth line of fortifications, located far to the west, outside the zone controlled by the royal army. It is possible that the ordering party required the author to provide such content. After all, it should be remembered that fortifications were a permanent and rather important element of many 18 th-century city maps (K. Nieścioruk 


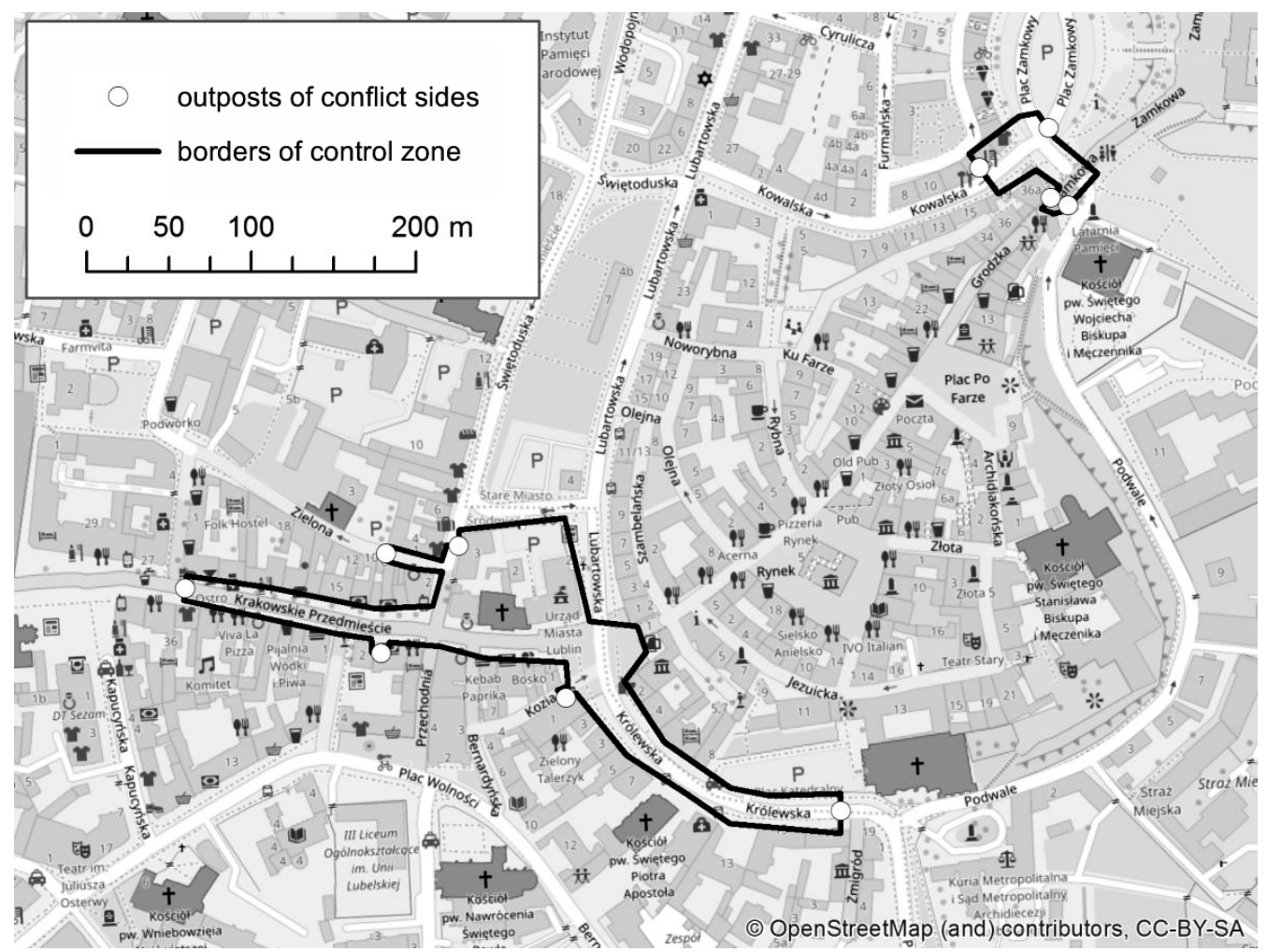

Fig. 3. Location of the outposts and approximate range of the zones controlled by both parties presented on a contemporary map

2007). What is more, cartography was often the responsibility of military engineers, especially in the army, who were also designers of fortifications. Thus, the map's detailed depiction of the fortification system could be the result of d'Örken's professional background and interests.

Lublin did not have a well-developed defence system, although its historic centre was surrounded by walls. Only a few elements have survived from this fortification system, among them the above-mentioned Krakowska and Grodzka Gates which are the end points of the Old Town's axis. The city walls are not only clearly visible on the map, but they are also the best examined element of Lublin's city fortifications, and actually the only one of which general public is aware (P. Targoński 2015). This is due to the fact that the remaining fortification lines were less durable and were constructed mostly of earth, with only some masonry elements. The fortification lines (especially the second, third and fourth lines) were built as rows stretched between the valleys of two rivers of Lublin Czechówka and Bystrzyca (J. Teodorowicz-Czerepińska et al. 1999). The Lublin Old Town is located on the headland of loess plateau at the meeting point between two valleys, so the lack of an extensive fortification system is partially explained by the good use of natural conditions. The last two lines of fortifications (3rd and 4th) are most clearly depicted on the map, although both of them are already identified as "old fortifications".

The third line of fortifications is not presented on the map in its full length (fig. 4). It was already almost a hundred years old at the beginning of the 18th century (it had been erected in 1620), and many of its fragments have been overtaken by the developing city or simply neglected. Its best preserved fragments were located in the 




Fig. 4. A part of the map showing the third line of fortifications

area of today's Litewski Square (the square wasn't established yet in 1716, but it was already the meeting point of the paths leading towards the Krakowska Gate). For some time, there was no agreement among the sources as to the location of this section of the fortifications. The belief that this line of fortifications used to run through the centre of the square first emerged in 1970s (J. Dybała 1972). It was supported by the analysis of d'Örken's city map and the fact that written sources confirmed that the fortification line was the basis of the border of the land belonging to the Capuchins (nowadays, the premises of the monastery end at Kościuszki Street which reaches Litewski Square). This location of the fortifications is also confirmed by their positioning in relation to the no-longer existing church of the Brothers Hospitallers of Saint John of God, which used to be located west of the fortifications, next to the moat. Archaeological research conducted on Litewski Square revealed that the remains of the church are located more or less in the southwestern part of the square (E. Mitrus, M. Matyaszewski 2000), which seemed to resolve the discussion concerning the location of the third fortification line. At the same time, other archaeological research carried out on the outskirts of Litewski Square suggested that the third fortification line could have been located along the line formed by Kołłątaja Street and 3 Maja Street (J. Teodorowicz-Czerepińska et al. 1999). However, this opinion was not supported by any other materials and was incompatible with the topography of objects in the area. A thorough analysis of the discussed map definitely confirmed the first of the above-mentioned hypotheses (K. Nieścioruk 2006), and the final proof was provided by the recent archaeological research conducted in connection with the reconstruction of Litewski Square. The works resulted in a discovery of such elements as a cemetery connected with the Church of Brothers Hospitallers, remains of walls (including fragments which are considered, albeit with a high degree of uncertainty, to have been connected with the gate in the fortification line), and foremost a very clear outline of a moat which run along the third line of fortifications (fig. 5). Figure 6 constitutes an attempt to combine the results of the archaeological works with the analysed city map.

The fourth line of fortifications was first built in the 1670s (P. Targoński 2015), so less than half a century before the city map was made.

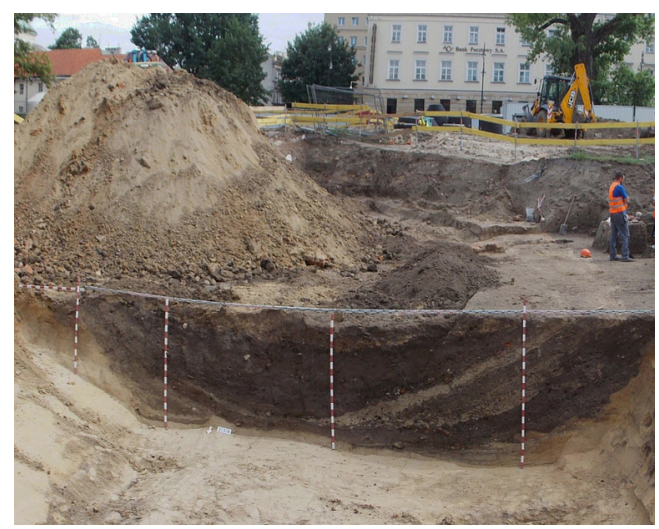

Fig. 5. A moat uncovered during archaeological works conducted on Litewski Square (photo by ARCHEE) 


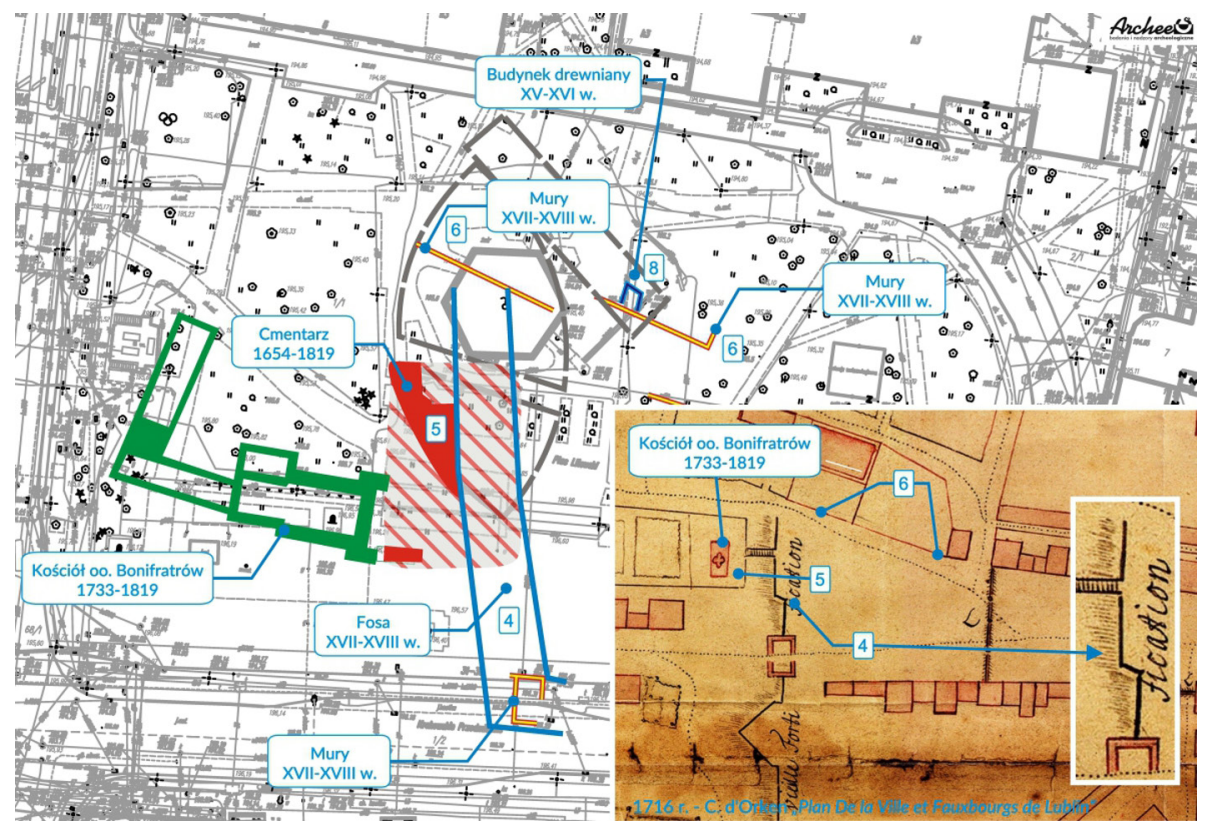

Fig. 6. The results of the archaeological research on Litewski Square combined with objects of d'Örken's map (prepared by ARCHEE), numbers mark the corresponding objects from the 1716 map and the contemporary basic map; descriptions from top to bottom: Wooden building 15th-16th c., Walls 17th-18th c., Walls, 17th-18th c., Cemetery 1654-1819, Church of Brothers Hospitallers of Saint John of God 1733-1819 (also on inlet), Moat 17th-18th c., Walls 17th-18th

Nevertheless, d'Örken was most likely not very impressed with its condition and potential for further exploitation, as he chose to describe it as "old", just as he did with the third line of fortifications. At the beginning of the 18th century, the fortifications were not yet absorbed by the city which was still almost in its entirety located within the fortification system. On the map, the fortifications are visible in their entire length, with all the details. It is in so far significant that some of these fortifications have been preserved to this day or have been discovered during archaeological works, and the entire fourth line significantly influenced the shape of the city in this area.

Figure 7 presents the content of d'Örken's map juxtaposed with a modern map (visualization of the OpenStreetMap database). It includes also such elements of the fortifications whose location is still noticeable to a naked eye (as they have been preserved or uncovered).

The hypothesis that there once existed two small redans in the southern part of the fortifica- tions was not clearly confirmed by archaeologists who supervised the infrastructure renovations of the area (P. Targoński 2015). However, the redans' distinctive shapes left their mark on the organisation of the area. As fortifications constitute special purpose areas which could remain excluded from any development investments for a long time, it is not surprising that they retained both their recognisable shapes and relations to other objects. It is particularly noticeable in the case of the cemetery's location in relation to Lipowa Street. One of the cemetery's sides is parallel to one of the faces of the redan, and not to the street itself, which would seem a more logical choice. The second redan (located more to the south of the city) also influenced the shape of the urban space - the 20th-century building is placed in relation to the street line in a manner which echoes the shape of the redan.

There are two interesting fortification works located to the north of the redans. The first is the bastion which has been uncovered during 


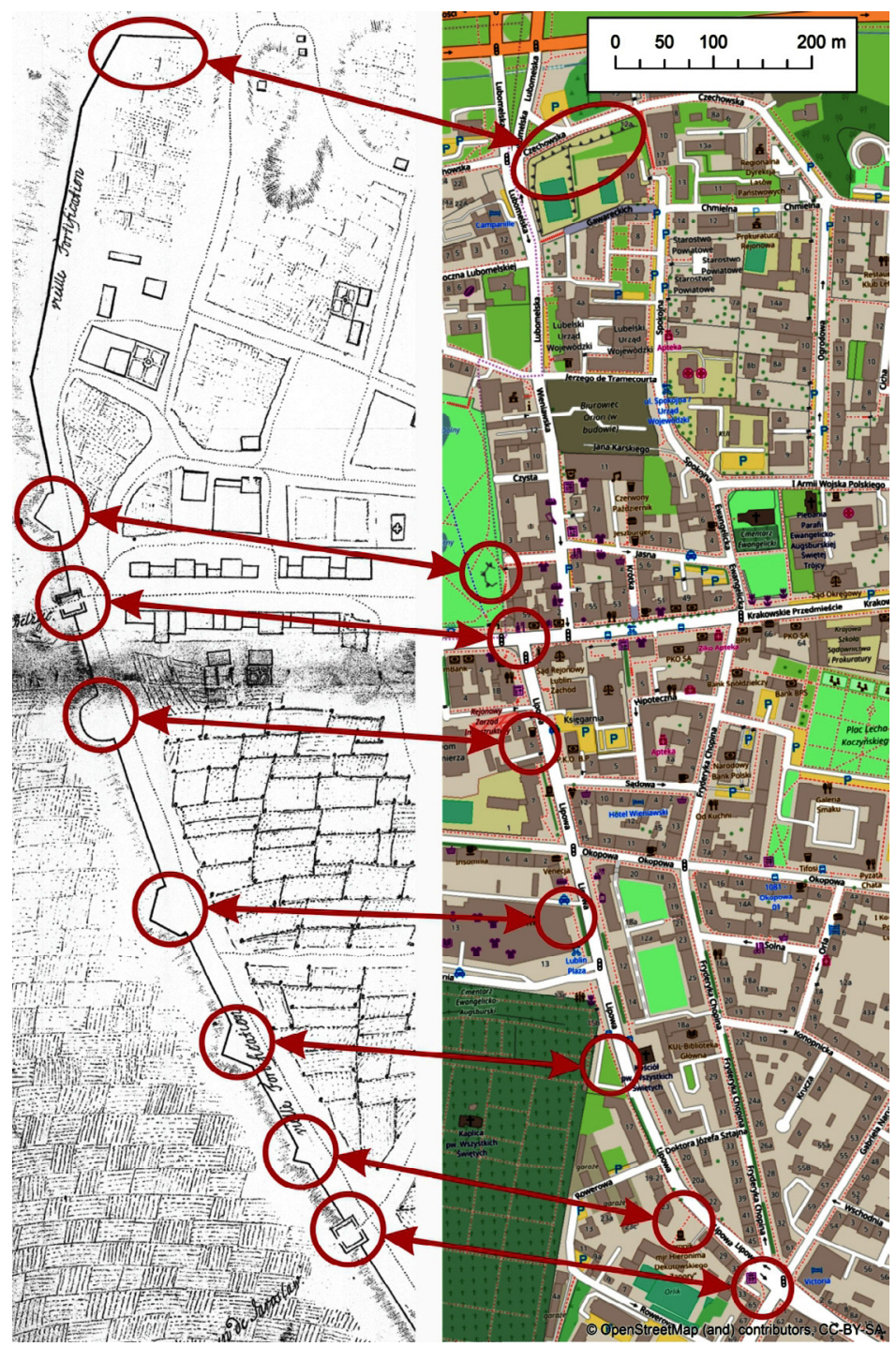

Fig. 7. Works of the fourth line of fortifications as depicted on d'Örken's map and the contemporary map

the construction of a shopping centre. It is a masonry work with walls whose thickness could have reached even the level of up to 1.05 metres and sides which were probably up to 16 -meters-long (P. Targoński 2015). The bastion was supposed to be displayed in the floor of a shopping centre with a so-called "window to the past" (a piece of transparent floor showing an archaeological dig with historic objects). Unfortu- nately, this project has not been implemented. It is an example of the city wasting the popularising potential of research related to the local history.

Another interesting fortification outwork is a brick roundel which was discovered in 1993 in the basements of the Piotrowski Palace at 5 Lipowa Street. Its remains were almost one-metre-wide and just over half-a-meter high 
(E. Mitrus 1995). The roundel's discovery constituted another material evidence proving that the content of d'Örken map correctly reflected the reality of its time (P. Targoński 2015). As an archaeological object, the roundel was much more important in the context of interpretation of the content related to the fourth line of fortifications than the redans, whose existence was never confirmed by any archaeological finds, even if they influenced the shape of the space much more clearly. The roundel was discovered more than a decade before excavation of preserved bastion remains, but the elements of the second bastion, which will be described in more detail below, were at that point perfectly noticeable to a naked eye. However, although the interpretation of the function of said elements leaves no place for doubts, there is no archaeological evidence that directly supports it.

There was another gate located north of the roundel, the so-called Holly Cross Gate (the second gate was located at the opposite end of the fortifications, near the intersection of $\mathrm{Li}$ powa and Narutowicza Streets). Unfortunately, archaeological studies have not brought any certain confirmation of its existence, except for small fragments of the wall (M. Matyaszewski 1972).

The aforementioned second bastion has been partly preserved to this day, as the hill at the main entrance to the Saxon Garden is believed to reflect its shape. It is worth noting that it is also the only element of Lublin's fortifications of which the city inhabitants could have been made aware in the recent years. First of all, it is easily accessible and visible (fig. 8), and secondly, when the renovation of the Saxon

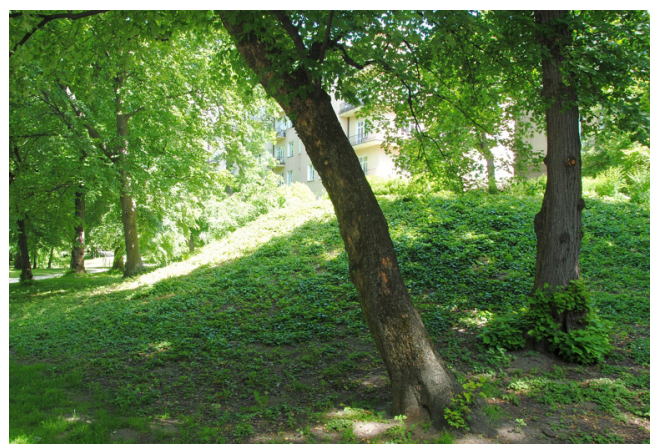

Fig. 8. Remains of the bastion in the Saxon Garden
Garden was completed in 2013 , the city put up information boards about interesting objects that could be found in the park which labelled it as a bastion.

\section{Conclusions}

The city map of Lublin created by C. d'Öken has many unique qualities. Its depiction of the city area is correct, although it contains not only topographic elements, but also objects drawn in a rather arbitrary manner, without any relation to their actual shape (such as the parish church). However, this should not surprising if one takes into consideration the purpose of the map. The task set for d'Örken was to provide spatial information about a specific event and the features of the city which were connected to that event in any way. Bearing that in mind, one can evaluate the map rationally, adjusting one's expectations accordingly. It is an interesting document of the city's history, albeit not a flawless one. Its analysis requires appropriate substantive and technical preparation. On the other hand, it is an unique historic source concerning a political event, i.e. the Tarnogród Confederation. Its function as a thematic map can be assessed in a similar manner. The uniqueness of the map is evidenced not only by its subject matter, but also by its very transience. Made with a specific date, it was valid for several months of the negotiations, depicting a small fragment of reality taking place within a short period of time.

The interesting characteristics of the map also include the element of its base content, i.e. the fortifications which are somewhat related to the main theme of the map. The fourth line of fortifications has particular significance in this context. Aside from the city walls, it is the only element of the fortifications which clearly influenced the contemporary space of the city. From the point of view of a cartography historian, the line is also important as proof of the quality of d'Örken's map. A superficial assessment of the map often led to drawing too hasty conclusions about its low quality, based mostly on its selective depiction of buildings or angular distortions of some areas. Yet, a more detailed analysis of the map, taking into consideration its purpose, significantly changed its perception and made it possible to reclassify it as a "thematic map" (K. Nieścioruk 2007). 
The results of the analysis draw attention to the need for adoption of a comprehensive approach to the study of old maps. It should be remembered that they were always created within the realities of a given era, in specific cultural contexts, within the limits of specific technological developments, and often in response to specific, sometimes very precisely defined needs. The only way to correctly ana-

\section{Literature}

Dybała J., 1972, Plac Litewski w Lublinie. Dzieje zabudowy i założenia urbanistycznego. "Roczniki Humanistyczne" T. 20, z. 5, pp. 71-100.

Dymmel P., 2007, Plany Lublina w zasobach archiwalnych. In: Plany i widoki Lublina XVII-XXI wiek, Lublin, pp. 88-97.

Gawarecki H., Lenart B., 1954, Najstarszy plan miasta Lublina z połowy XVII wieku i jego konserwacja. “Ochrona Zabytków” R. 7, nr 3, pp. 197-199.

Kociuba D., 2003, Zmiany funkcji dolin rzecznych na obszarze Lublina. "Annales UMCS", Sectio B, Vol. 58, pp. 121-137.

Matyaszewski M., 1972, Dokumentacja z nadzorów archeologicznych nad pracami ziemnymi związanymi z wymianą instalacji w ulicy Krakowskie Przedmieście w Lublinie. Lublin.

Mitrus E., 1995, Nowe odkrycia archeologiczne elementów systemów obronnych miasta Lublina. "Lubelszczyzna" Nr 1, pp. 4-19.

Mitrus E., Matyaszewski M., 2000, Dokumentacja z badań archeologicznych reliktów kościoła o.o. Bonifratrów na Placu Litewskim w Lublinie. Lublin.

Nieścioruk K., 2006, Metodyczne aspekty kartograficznej analizy i oceny dawnych planów miast na przykładzie planu Lublina z 1716 roku C. d’Örkena. lyse old maps is to take many such factors into account.

\section{Acknowledgements}

The author would like to thank Mr. Rafał Niedźwiadek from ARCHEE for providing him with materials from the archaeological works conducted on Litewski Square and the consent for their publication.

Unpublished Ph. Dr. dissertation. Department of Cartography, Maria Curie-Skłodowska University in Lublin.

Nieścioruk K., 2007, Analiza i ocena XVIII-wiecznego planu Lublina jako przykład kompleksowych badań dawnych materiałów kartograficznych. "Polski Przegląd Kartograficzny" T. 39, nr 2, pp. 146-158.

Targoński P., 2015, Czwarta linia nowożytnych fortyfikacji Lublina z lat 1667-1670. „Rocznik Lubelski” T. 41, pp. 9-32.

Teodorowicz-Czerepińska J., Michalska G., Michalski Ł., 1999, Ochrona fortyfikacji miejskich w planach zagospodarowania przestrzennego na przykładzie Lublina. In: Lokalne programy ochrony i zagospodarowania zabytkowych zespołów obronnych. "Fortyfikacje" T. 8, Warszawa, pp. 120-135.

\section{City map}

C. d'Örken, Plan de la ville et fauxbourgs de Lublin. Scale c. $1: 3600,1716,78 \times 56 \mathrm{~cm}$, northern orientation. Wojewódzka Biblioteka Publiczna im. H. Łopacińskiego in Lublin, Zbiory Specjalne (sygn. 1/NI). Copy in: Plany $i$ widoki Lublina XVII-XXI wiek, Lublin 2007. 